\title{
PENGARUH KEMAMPUAN MEMBACA DAN MENULIS TERHADAP KEMAMPUAN MENYELESAIKAN SOAL CERITA MATEMATIKA
}

\author{
Ritno $^{1}$ \\ Abd Rahman Rahim ${ }^{2}$ \\ Andi Sukri Syamsuri ${ }^{3}$ \\ ${ }^{1}$ SDN 171 Inpres Kaluku Kecamatan Cenrana, Kabupaten Maros \\ ${ }^{2,3}$ Magister Pendidikan Bahasa Indonesia, Universitas Muhammadiyah Makassar \\ ritnospd@gmail.com ${ }^{1)}$ \\ rahman@unismuh.ac.id ${ }^{2 *}$ \\ andhies@unismuh.ac.id ${ }^{3}$
}

\begin{abstract}
Abstrak
Tujuan penelitian ini adalah untuk mendeskripsikan pengaruh kemampuan membaca dan menulis terhadap kemampuan menyelesaikan soal cerita matematika. Desain kuantitatif dengan metode inferensial-korelasional digunakan untuk menyelidiki kemampuan membaca siswa, kemampuan menulis siswa, dan kemampuan menyelesaikan soal cerita siswa. 19 siswa berpartisipasi dalam penelitian ini. Data yang dikumpulkan berupa: (1) data kuantitatif jenis scala, berupa angka-angka; (2) tes yang meliputi pengetesan terhadap kemampuan membaca, pengetesan terhadap kemampuan menulis, dan pengetesan terhadap kemampuan menyelesaikan soal cerita matematika. Untuk mengetahui hubungan variabel yang telah ditentukan, maka teknik statistik inferensial dengan regresi linear berganda sederhana digunakan. Hasil yang ditemukan adalah: (1) Tingkat kemampuan membaca dan menyelesaikan soal cerita berada pada kategori sedang; (2) Terdapat pengaruh signifikan kemampuan membaca terhadap kemampuan menyelesaiakn soal cerita matematika; (3) Terdapat pengaruh signifikan kemampuan menulis terhadap kemampuan menyelesaikan soal cerita matematika; (4) Terdapat pengaruh signifikan secara bersama-sama kemampuan membaca dan menulis terhadap kemampuan menyelesaikan soal cerita.
\end{abstract}

Kata Kunci: Kemampuan Membaca, Kemampuan Menulis, Soal Cerita Matematika

Published by:

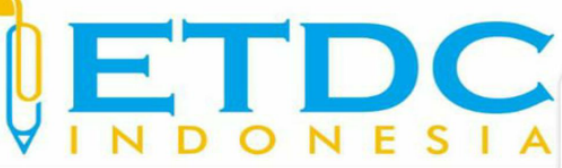

Copyright (C) 2021 The Author (s)

This article is licensed under CC BY 4.0 License

(cc) BY 


\section{PENGARUH KEMAMPUAN MEMBACA DAN MENULIS TERHADAP KEMAMPUAN MENYELESAIKAN SOAL CERITA MATEMATIKA}

\section{Pendahuluan}

Pentingnya membaca menulis dan berhitung menjadi langkah awal yang harus para anak kuasai pada pendidikan di sekolah dasar. Dalam Undang-Undang No. 20 Tahun 2003 tentang Sistem Pendidikan Nasional memuat isi kurikulum Pendidikan Dasar yang antara lain tercakup di dalamnya bahan kajian membaca dan menulis (Bahasa Indonesia) serta matematika (termasuk berhitung). Dihubungkan dengan percepatan pengusaan ilmu pengetahuan dan teknologi yang amat diperlukan dalam pembangunan, maka pengusaan dan kecakapan bacatulis-hitung ini amat strategis sifatnya. Di satu segi kelemahan dan kekurangan siswa dalam baca-tulis-hitung dapat menjadi kendala bagi pengenalan dan pengusaan teknologi, sedangkan di sisi lain dapat pula menjadi kendala bagi kelanjutan pendidikan peserta didik. Adalah menjadi tugas dan tanggung jawab kita bersama untuk melaksanakan amanat tersebut dengan sebaik-baiknya. Sedankan dalam kurikulum 2013 ditegaskan bahwa bahasa Indonesia berfngsi sebagai penghela mata pelajaran lain. Oleh karena itu penguasaan bahasa Indonesia tentu dapat berimplikasi dengan penguasaaan mata pelahjaran lainnya, seperti IPA, Matematika, Pkn, dan sebaginya.

Pembelajaran bahasa diarahkan kepada mempertajam kepekaan perasaan siswa. Siswa tidak hanya diharapkan mampu memahami informasi yang disampaikan secara lugas atau secara langsung, melainkan juga yang disampaikan secara terselubung atau secara tidak langsung. Pembelajaran bahasa, selain untuk meningkatan keterampilan berbahasa, juga untuk meningkatkan kemampuan berpikir dan bernalar, serta kemampuan memperluas wawasan. Bahan pelajaran bahasa dan sastra Indonesia dapat dipadukan atau dikaitkan dengan mata pelajaran lain, seperti Matematika, IPA atau IPS.

Siswa SD akan dapat mengerjakan soal cerita dalam matematka jika mereka telah memiliki kemampuan dasar yaitu membaca (bahasa Indonesia) menulis dan berhitung. Memang banyak faktor yang memengaruhi proses belajar dan hasil belajar matematika, yaitu individu dan faktor yang berasal dari luar diri individu. Faktor dari diri individu antara lain kognitif, afektif, psikomotor, kepribadian, cacat fisik, sedangkan faktor dari luar diri individu yang memengaruhi proses dan hasil belajar matematika antara lain lingkungan alam, sosial ekonomi guru, metode mengajar, kurikulum, program materi pelajaran, sarana dan prasarana.

Akan tetapi, dalam memperlajari matematika penguasaan bahasa Indonesia terutama 
membaca dan menulis merupakan landasan yang kuat guna melangkah lebih jauh untuk mendalami matematika. Tidak mungkin siswa dapat menyelesaikan soal cerita matematika tanpa mengetahui terlebih dahulu makna yang terkandung dari soal cerita matematika. Untuk memahami makna kalimat ini, anak harus dapat membaca terlebih dahulu. Sedangkan ketidakmampuan membaca dan menulis bahasa Indonesia dapat menimbulkan kesulitan siswa dalam mempelajari matematka.

Untuk itu kemampuan membaca dan menulis bahasa Indonesia harus dikuasai oleh siswa. Di samping kemampuan melakukan komputasi atau berhitung juga harus dikuasai. Karena kedua hal tersebut sangat diperlukan untuk memahami dan menyelesaikan soal cerita matematika . Namun, sampai sekarang belum diketahui secara ilmiah hubungan penguasaan bahasa Indonesia dengan kemampuan menyelesaikan soal cerita matematika .

Keterampilan membaca adalah salah satu keterampilan reseptif di samping keterampilan mendengarkan. Sebagai salah satu keterampilan reseptif, membaca merupakan komponen pemahaman. Bahan pembelajaran keterampilan membaca merupakan wacana tulis, baik wacana sastra maupun nonsastra. Dalam kegiatan pembelajaran membaca, selain guru dituntut untuk memahami kurikulum agar dapat memahami dan menguasai materi pembelajaran, guru juga harus mampu merancang pembelajaran lebih menyenangkan dan bermakna. Pada akhirnya, pada saat pelaksanaan pembelajaran membaca di kelas, guru tidak sekadar menugasi siswa membaca (dalam hati) sebuah wacana kemudian mengerjakan tugastugas yang ada dalam wacana tersebut.

Selain itu, menulis termasuk aspek kegiatan berbahasa yang dianggap sulit. Hal itu dikeluhkan oleh banyak orang. Menulis seperti halnya kegiatan berbahasa lainnya, merupakan keterampilan. Setiap keterampilan hanya akan diperoleh melalui berlatih. Berlatih secara sistematis, terus-menerus, dan penuh disipilin merupakan resep yang selalu disarankan oleh praktisi untuk dapat atau terampil menulis. Tentu saja bekal untuk berlatih bukan hanya sekedar kemauan, tetapi juga ada bekal lain yang perlu dimiliki. Bekal lain itu adalah pengetahuan, konsep, prinsip, dan prosedur yang harus ditempuh dalam kegiatan menulis. Jadi ada tiga hal yang diperlukan untuk mencapai ketrampilan menulis yakni pengetahuan tentang tulis-menulis dan berlatih untuk menulis, serta pengetahuan tentang apa yang akan ditulis. Keterampilan menulis pada hakikatnya memproduksi kembali informasi dan ide-ide ke dalam tulisan. Dengan menulis, seseorang dapat menggambarkan pola pikirannya dalam menuangkan informasi dan ide-ide tersebut juga dapat menyelesaikan masalah, termasuk dalam hal matematis.

Berdasarakan uraian di atas, maka kami terdorong untuk melakukan penelitian mengenai pengaruh kemampuan membaca dan menulis terhadap kemampuan siswa 
menyelesaikan soal cerita matematika. Hal ini perlu dikaji karena pada kenyataannya untuk memperbaiki keterampilan berbahasa siswa seringkali tidak memperhatikan keseimbangan keterampilan berbahasa tersebut khusnya membaca dan menulis dan berhitung termasuk soal cerita matematika. Kemampuan mebaca dan menulis dianggap berpengaruh terhadap kemampuan menyelesaikan soal cerita matematika karena matematika tersebut menjadikan menulis dan mebaca sebagaian dari kompetensi syarat untuk menyelesaikan kalimat matetimaka bagi siswa. Penelitian ini dianggap penting selain hal ini merupakan pembuktian konsep di atas, juga merupakan jawaban atas fenomenda rendahnya kemampuan matematis siswa di sekolah tersebut masih memiliki kemamuan membaca dan menulis yang rendah juga memiliki kemampuan matematis terutama menyelesaikan soal cerita yang rendah.

Berdasarkan uraian pada latar belakangan masalah di atas, maka kami berupaya menjawab rumusan masalah sebagai berikut "bagaimana pengaruh kemampuan membaca dan menulis terhadap kemampuan menyelesaikan soal cerita matematika?"

\section{Metode Penelitian}

Penelitian ini merupakan penelitian kuantitaif, dilihat dari segi jenis data. Penelitian ini didesain sebagai penelitian inferensial-korelasional yang berpya melihat pengaruh variabel bebas terhadap varibel terikat. Penelitian dilakukan dengan beberapa tahapan yakni: (1) pengetesan terhadap variabel bebas 1 (X1) yaitu kemampuan membaca siswa (2) pengetesan terhadap variabel bebas 2 (X2) yakni kemampuan menulis siswa, (3) pengetesan terhadap variabel terikat (Y) yakni kemampuan menyelesaikan soal cerita siswa, (4) nanalisis pengaruh vaiabel bebas terhadap varibel terikat.

\subsection{Populasi dan Sampel}

Populasi penelitian ini adalah semua siswa kelas siswa kelas IV SDN 171 Inpres Kaluku Kecamatan Cenrana, Kabupaten Maros, tahun pelajaran 2020/2021. Populasi tersebut berjumlah 19 orang. Karena populasi dalam penelitian ini jumlahnya kecil, maka digunakan teknik sampel tolat (total sampling) yakni $100 \%$ populasi dijadikan subjek penelitian. Hal ini sesuai dengan ketentuan yang dikemukakan oleh Arikunto (2011: 107) bahwa pengambilan sampel dari populasi yang kecil dapat diambil sampel seluruhnya (100\%). Jadi, jumlah siswa yang menjadi sampel penelitian adalah sebanyak 9 orang.

\subsection{Pengumpulan Data}

Metode pengumpulan data dalam penenlitian ini diuraikan sebagai berikut. Pertama, jenis data dalam penelitian ini adalah data kuantitatif jenis scala, berupa angka-angka. Kedua, sumber data dalam penelitian ini adalah siswa kelas V, SDN 171 Inpres Kaluku Kecamatan 
Cenrana, Kabupaten Maros sejumlah 31 orang. Ketiga, teknik pengumpulan data dalm penelitian ini adalah teknik tes. Tes tersebut meliputi tiga hal yaitu (a) Pengetesan terhadap kemampuan membaca (b) Pengetesan terhadap kemampuan menulis (3) Pengetesan terhadap kemampuan menyelesaikan soal cerita matematika. Tes tersebut berupa soal-soal berdasarkan kurikulum 2013 sesuai tingkatan kelas IV yang telah dipelajari siswa.

\subsection{Definisi Operasional}

Penelitian ini mengamati tiga variabel, pertama, dua variabel bebas, yakni: (1) variabel bebas (X1) kemampuan membaca siswa; dan (2) ariabel bebas (X2) kemampuan menulis. Kedua, satu variabel terikat, yakni: kemampuan menyelesaikan soal cerita matematika. Ketiga variabel tersebut diteliti dengan beberapa tahap, yaitu: (1) Melakukan pengetesan terhadap kemampuan membaca siswa sampel; (2) Melakukan pengetesan terhadap kemampuan menulis siswa sampel; (3) Melakukan pengetesan terhadap kemampuan menyeleaikan soal cerita matematika mateika siswa sampel; dan (4) Melakukan analisis sesuai prosedur (analisis regesi sederhana) dan menafsirkannya. Oleh karena itu, untuk lebih mudah memahami penelitian ini dan menghindari kesimpangsiuran pemahaman dalam penulisan ini maka dikemukakan definisi operasional variabel sebagai berikut

1. Kemampuan membaca yang adalah nilai atau skor kegiatan memahami isi keseluruhan, topik, ide pokok, kesimpulan, dan makna kosakata alam membaca siswa.

2. Kemampuan menulis secara operasional yang dimaksud adalah skor kemampuan siswa dalam mengembangkan kalimat menjadi paragraf, menulis kalimat matematika, menulis keterhubunga, menulis jwaban sera sistematis dan logis.

3. Kemampuan menyelesaikan soal cerita matematika adalah skor hasil penyelesaian matematika siswa dari soal cerita matematika berupa cerita yang mengandung kalimat matematika yang membutuhkan analisis dan interpretasi matematis dan diselesaikan dengan perhitungan matematis

\subsection{Analisis Data}

Untuk mengetahui ada-tidaknya hubungan variabel yang telah ditentukan, maka data dalam penelitian ini dianalisis dengan menggunakan teknik statistik inferensial atas rancangan analisis, regresi linear berganda sederhana yaitu dengan rumus regresi linear sederhana sebagai berikut.

$$
\mathrm{Y}^{\prime}=\mathrm{a}+\mathrm{bX} 1 \mathrm{X} 2
$$

\section{Keterangan:}

$\mathrm{Y}^{\prime}=$ Kemampuan menyelesaikan soal cerita (Variabel dependen: /nilai yang diprediksikan) 
$\mathrm{X} 1$ = Kemampuan membaca (Variabel independen)

$\mathrm{X} 2$ = Kemampuan menulis (Variabel independen)

a $=$ Konstanta (nilai $Y^{\prime}$ apabila $\mathrm{X}=0$ )

$\mathrm{b}=$ Koefisien regresi (nilai peningkatan ataupun penurunan)

Analisis di atas menggunakan bantuan analisis komputer aplikasi dengan program $A d d-$ Ins Analysis ToolPak of Excel.

\section{Hasil dan Pembahasan}

\subsection{Data tingkat kemampuan membaca}

Data tingkat kemampuan membaca dapat dilihat pada Tabel 2 berikut.

Tabel 2. Tingkat kemampuan membaca siswa kelas IV SD Inpres Kaluku Kecamatan Cenrana Kabupaten Maros

\begin{tabular}{cccc}
\hline NO & NILAI & F & N X F \\
\hline 1 & 100 & 0 & 0 \\
\hline 2 & 90 & 0 & 0 \\
\hline 3 & 80 & 2 & 160 \\
\hline 4 & 70 & 7 & 490 \\
\hline 5 & 60 & 8 & 480 \\
\hline 6 & 50 & 2 & 100 \\
\hline 7 & 40 & 0 & 0 \\
\hline 8 & 30 & 0 & 0 \\
\hline 9 & 20 & 0 & 0 \\
\hline 10 & 10 & 0 & 1230 \\
\hline & JUMLAH & 31 &
\end{tabular}

Sumber: hasil olah data penelitian

Berdasarkan hasil analisis data di atas dapat diketahui:

$\begin{array}{lll}\mathrm{N} & =19 \\ \mathrm{FN} & =1240\end{array}$

Dengan demikian skor rata-rata yaitu:

$$
\begin{array}{ll}
\text { Rata-rata } & : \mathrm{FN} / \mathrm{n} \times 100 \% \\
\text { Rata-rata } & : 1240 / 19 \times 100 \% \\
\text { Rata-rata } & : 65,26
\end{array}
$$

Jadi, rata-rata tingkat kemampuan membaca siswa adalah 65,26 dalam rentangan nilai 10-100. Selain itu, berdasarkan hasil analisis data mentah terlihat bahwa skor perolehan tertinggi adalah 81 dari skor maksimun 100 sebanyak satu orang. Sedangkan skor terendah adalah 49 yang diperoleh oleh satu orang, Selanjutnya dikonversi dengan tabel kategori nilai sesuai dengan pedoman penilaian di sekolah dasar sebagai berikut: maka dapat dinyatakan tingkat tingkat kemampuan membaca siswa berada pada kategori sedang. 


\subsection{Data tingkat kemampuan menulis siswa}

Data tingkat kemampuan menulis siswa kelas IV SD Inpres Kaluku Kecamatan Cenrana, Kabupaten Maros dapat dilihat pada Tabel 3 berikut.

Tabel 3. Tingkat kemampuan menulis sisawa

\begin{tabular}{cccc}
\hline NO & NILAI & F & N X F \\
\hline 1 & 100 & 0 & 0 \\
\hline 2 & 90 & 0 & 0 \\
\hline 3 & 80 & 1 & 80 \\
\hline 4 & 70 & 9 & 630 \\
\hline 5 & 60 & 8 & 480 \\
\hline 6 & 50 & 1 & 50 \\
\hline 7 & 40 & 0 & 0 \\
\hline 8 & 30 & 0 & 0 \\
\hline 9 & 20 & 0 & 0 \\
\hline 10 & 10 & 0 & 1230 \\
\hline & JUMLAH & 31 &
\end{tabular}

Sumber: hasil olah data penelitian

Berdasarkan hasil analisis data di atas dapat diketahui:

$\begin{array}{lll}\mathrm{N} & =19 \\ \mathrm{FN} & =1230\end{array}$

Dengan demikian skor rata-rata yaitu:

$$
\begin{array}{ll}
\text { Rata-rata } & : \mathrm{FN} / \mathrm{n} \times 100 \% \\
\text { Rata-rata } & : 1230 / 19 \times 100 \% \\
\text { Rata-rata } & : 64,74
\end{array}
$$

Jadi, rata-rata tingkat kemampuan menulis siswa kelas IV SD Inpres Kaluku Kecamatan Cenrana, Kabupaten Maros adalah 64,74 alam rentangan nilai 10-100. Selain itu, berdasarkan hasil analisis data mentah terlihat bahwa skor perolehan tertinggi adalah 80 dari skor maksimun 100 sebanyak satu orang. Sedangkan skor terendah adalah 409 yang diperoleh oleh satu orang, Berdasarkan tabel, maka dapat dinyatakan bahwa tingkat kemampuan menulis siswa kelas IV SD Inpres Kaluku Kecamatan Cenrana, Kabupaten Maros berada pada kategori kurang.

\subsection{Data tingkat kemampuan menyelesaikan soal cerita siswa}

Data tingkat kemampuan menulis siswa kelas IV SD Inpres Kaluku Kecamatan Cenrana, Kabupaten Maros dapat dilihat pada Tabel 4 berikut. 
Tabel 4. Tingkat kemampuan menyelesaikan soal cerita siswa kelas IV SD Inpres Kaluku Kecamatan Cenrana, Kabupaten Maros

\begin{tabular}{cccc}
\hline NO & NILAI & F & N X F \\
\hline 1 & 100 & 0 & 0 \\
\hline 2 & 90 & 0 & 0 \\
\hline 3 & 80 & 0 & 0 \\
\hline 4 & 70 & 6 & 620 \\
\hline 5 & 60 & 11 & 50 \\
\hline 6 & 50 & 1 & 40 \\
\hline 7 & 40 & 1 & 0 \\
\hline 8 & 30 & 0 & 0 \\
\hline 9 & 20 & 0 & 0 \\
\hline 10 & 10 & 0 & 1170 \\
\hline
\end{tabular}

Sumber: hasil olah data penelitian

Berdasarkan hasil analisis data di atas dapat diketahui:

$\mathrm{N}=31$

$\mathrm{FN}=1780$

Dengan demikian skor rata-rata yaitu:

$\begin{array}{ll}\text { Rata-rata } & : \mathrm{FN} / \mathrm{n} \times 100 \% \\ \text { Rata-rata } & : 1170 / 19 \times 100 \% \\ \text { Rata-rata } & : 61,59\end{array}$

Jadi, rata-rata tingkat kemampuan menyelesaikan soal cerita siswa kelas IV SD Inpres Kaluku Kecamatan Cenrana, Kabupaten Maros adalah 61,59 dalam rentangan nilai 10-100. Selain itu, berdasarkan hasil analisis data mentah terlihat bahwa skor perolehan tertinggi adalah 79 dari skor maksimun 100 sebanyak satu orang. Sedangkan skor terendah adalah 44 yang diperoleh oleh satu orang, Jumlah seluruh skor seluruh murid yaitu 1780, sehingga rata-rata skor perolehan siswa adalah 5,42. Berdasarkan tabel di atas, maka dapat dinyatakan bahwa ingkat kemampuan menyelesaikan soal cerita siswa kelas IV SD Inpres Kaluku Kecamatan Cenrana, Kabupaten Maros. berada pada kategori sedang.

\subsection{Pengujian Hipotesis (variabel X1 terhadap Y): Pengaruh kemampuan membaca terhadap kemampuan menyelesaikan soal cerita matematika siswa}

Untuk menentukan ada-tidaknya pengaruh antara variabel kemampuan membaca tehadap varaiabel kemampuan menyelesaikan soal cerita matematika, maka data dari kedua variabel dianalisis dengan menggunakan komputer prgram Add-Ins Analysis ToolPak of Excel. Adapun ringkasan hasil analisis regresi variabel maka dikemukakan ringkasan hasil analisis data sebagai berikut. 


\begin{tabular}{lllll}
\hline & Coefficients & $\begin{array}{l}\text { Standard } \\
\text { Error }\end{array}$ & t Stat & P-value \\
\hline Intercept & 21,71848 & 7,445644 & 2,916937 & 0,009611 \\
\hline Membaca (X1) & 0,691599 & 0,112775 & 6,132574 & $1,11 \mathrm{E}-05$ \\
\hline
\end{tabular}

a. Dependent Variable: membaca (X1)

b. Predictors: (Constant), menyelesaikan soal cerita (Y)

Dari Tabel di atas dikemukakan:

Hipotesis:

Ho: Tidak ada pengaruh signifikan antara variable kemampuan membaca terhadap kemampuan menyelesaikan soal cerita matematka

H1: Terdapat pengaruh signifikan antara variable kemampuan membaca terhadap kemampuan menyelesaikan soal cerita matematka
Alpha $\quad:(0,05)$
P-value $\quad: 0,009611$

Kriteria uji : Ho ditolak jika jika P-value $<$ alpha $(0,05)$

Keputusan : Ho ditolak jika karena P-value $(0,009611)<$ alpha $(0,05)$

Kesimpulan : dengan menggunakan taraf signifikansi 5\%, maka sampel yang ada memberikan kesimpulan bahwa terdapat pengaruh signifikans kemampuan membaca terhadap kemampuan menyelesaiakn soal cerita matematika kelas IV SD Inpres Kaluku Kecamatan Cenrana, Kabupaten Maros.

Adapun koofisien determinasi atau besaran kemampuan varaibel $\mathrm{X}$ (kemampuan membaca) dalam pengaruh terhadap variabel Y (menyelesaikan soal cerita) dapat dilihat pada R-suere berikut.

\begin{tabular}{lr}
\hline & Regression Statistics \\
\hline Multiple R & 0,829875265 \\
R Square & 0,388692955 \\
Adjusted R Square & 0,670380776 \\
Standard Error & 4,175307714 \\
Observations & 19 \\
\hline
\end{tabular}

Berdasarkan hasil rinmgkasan koofisien determinasi di atas dapat diperoleh nilai RSquare: 0,388692955 yang artinya bahwa variabel kemampuan membaca mempengaruhi kemampuan menyelesaikan soal cerita $38,87 \%$, sisanya dipengaruhi oleh variabel lain yang tidak dibahas. 


\subsection{Pengujian Hipotesis (variabel $\mathrm{X} 2$ terhadap Y): Pengaruh kemampuan menulis} terhadap kemampuan menye-lesaikan soal cerita matematika siswa

Adapun ringkasan hasil analisis regresi variabel kemampuan menulis terhadap kemampuan menyelesaikan soal cerita matematika adalah sebagai berikut.

\begin{tabular}{lllll}
\hline & Coefficients & $\begin{array}{l}\text { Standard } \\
\text { Error }\end{array}$ & t Stat & P-value \\
\hline Intercept & 21,25370943 & 7,291842 & 2,914724 & 0,009656 \\
\hline MENULIS (x2) & 0,700386399 & 0,110713 & 6,326118 & $7,6 \mathrm{E}-06$ \\
\hline
\end{tabular}

a. Dependent Variable: menulis (X2)

b. Predictors: (Constant), menyelesaikan soal cerita (Y)

Dari tabel di atas dikemukakan:

Hipotesis:

Ho: Tidak ada pengaruh signifikan antara variable kemampuan menulis terhadap kemampuan menyelesaikan soal cerita matematka

H1: Terdapat pengaruh signifikan antara variable kemampuan menulis terhadap kemampuan menyelesaikan soal cerita matematka

alpha $\quad:(0,05)$

P-value : :0,009656

Kriteria uji : Ho ditolak jika jika $\mathrm{P}$-value $<$ alpha $(0,05)$

Keputusan : Ho ditolak jika karena P-value $(0,009656)<$ alpha $(0,05)$

Kesimpulan: Dengan menggunakan taraf signifikansi 5\%, maka sampel yang ada memberikan kesimpulan bahwa terdapat pengaruh signifikans kemampuan menulis terhadap kemampuan menyelesaiakn soal cerita matematika kelas IV SD Inpres Kaluku Kecamatan Cenrana, Kabupaten Maros.

Adapun koofisien determinasi atau besaran kemampuan varaibel X (kemampuan menulis) dalam pengaruh terhadap variabel Y (menyelesaikan soal cerita) dapat dilihat pada R-suere berikut.

\begin{tabular}{lr}
\hline & Regression Statistics \\
\hline Multiple R & 0,837769538 \\
R Square & 0,201857799 \\
Adjusted R Square & 0,684320022 \\
Standard Error & 4,086069416 \\
Observations & 19 \\
\hline
\end{tabular}

Berdasarkan hasil rinmgkasan koofisien determinasi di atas dapat diperoleh nilai RSquare: 0,201857799 yang artinya bahwa variabel kemampuan membaca mempengaruhi kemampuan menyelesaikan soal cerita $20,186 \%$, sisanya dipengaruhi oleh variabel lain yang 
tidak dibahas.

\subsection{Pengujian Hipotesis (variabel X1 dan X2 terhadap Y): Pengaruh secara bersama- sama/simultan kemampuan membaca dan menulis terhadap kemampuan menyelesaikan soal cerita matematika siswa}

Adapun ringkasan hasil analisis regresi variabel kemampuan membaca dan menulis secara bersama-sama/simultan terhadap kemampuan menyelesaikan soal cerita matematika adalah sebagai berikut.

\begin{tabular}{lllll}
\hline & Coefficients & Standard Error & $t$ Stat & $P$-value \\
\hline Intercept & 21,36371629 & 7,462765 & 2,862708 & 0,01128 \\
\hline MENULIS (x2) & 1,408441002 & 1,436039 & 0,980782 & 0,34129 \\
\hline
\end{tabular}

a. Dependent Variable: membaca dan menulis (X1 dan X2)

b. Predictors: (Constant), menyelesaikan soal cerita (Y)

Dari tabel di atas dikemukakan:

Hipotesis:

Ho: Tidak ada pengaruh signifikan secara bersama-sama antara variable kemampuan membaca dan kemampuan menulis meterhadap kemampuan menyelesaikan soal cerita matematka

H1: Terdapat pengaruh signifikan secara bersama-sama antara variable kemampuan membaca dan kemampuan menulis meterhadap kemampuan menyelesaikan soal cerita matematka

alpha $\quad:(0,05)$

P-value $\quad: 0,01128$

Kriteria uji : Ho ditolak jika jika P-value $<$ alpha $(0,05)$

Keputusan : Ho ditolak jika karena P-value $(0,01128)<$ alpha $(0,05)$

Kesimpulan: Dengan menggunakan taraf signifikansi 5\%, maka sampel yang ada memberikan kesimpulan bahwa terdapat pengaruh signifikans secara bersam-sama kemampuan membaca dan kemampuan menulis terhadap kemampuan menyelesaiakn soal cerita matematika kelas IV SD Inpres Kaluku Kecamatan Cenrana, Kabupaten Maros.

Adapun koofisien determinasi atau besaran kemampuan varaibel $\mathrm{X}$ (kemampuan menulis) dalam pengaruh terhadap variabel Y (menyelesaikan soal cerita) dapat dilihat pada R-suere berikut.

\begin{tabular}{lr}
\hline \multicolumn{2}{c}{ Regression Statistics } \\
\hline Multiple R & 0,840444865 \\
R Square & $2,19063 \mathrm{E}+15$ \\
Adjusted R Square & $\mathbf{0 , 1 8 9 6 4 1 0 1 7}$ \\
Standard Error & 4,179990374
\end{tabular}


Observations

19

Berdasarkan hasil rinmgkasan koofisien determinasi di atas dapat diperoleh nilai Adjusted R Square: 0,189641017 yang artinya bahwa secara bersama-sama variabel kemampuan membaca dan menulis mempengaruhi kemampuan menyelesaikan soal cerita $18,964 \%$, sisanya dipengaruhi oleh variabel lain yang tidak dibahas.

\subsection{Pembahasan}

Berdasarkan hasil pengolahan data di atas, maka dapat diketahui bahwa rata-rata nilai tingkat kemampuan membaca siswa k berada pada kategori masih sedang. Sedangkan tingkat kemampuan menulis siswa berada juga pada kategori sedang. Demikian pula kemampuan menyelesaikan soal cerita berada pada kategir sedang. Data hasil analisis juga menunjukkan bahwa kemampuan membaca siswa berpengaruh terhadap kemampuan menyelesaikan soal ceritasiswa. Artinya, secara signfikan, kemampuan membaca memiliki kontribusisebesar $38,87 \%$, terhadap kemampuan menyelesaikan soal cerita. Demikian halnya dengan kemampuan menulis memiliki kontribusi sebesar 20,186\%, terhadap kemampuan menyelesaikan soal cerita. Secara bersama-sama kemampuan membaca dan menulis juga memiliki kontribusi sebesar 18,964\%, terhadap kemampuan menyelesaikan soal cerita

Hasl penelitian ini sesuai dengan pandangan Tarigan (2014) menyatakan membaca, menulis dan berpikir matematis yaitu membaca adalah merupakan proses awal yang melatih dan meningkatkan keterampilan bahasa lisan sehingga mampu mengembangkan keterampilan bahasa tulis dalam menyelesaikan persoaln kehidupan.

Pandangan ini relevan dengan konsep yang dikemukakan oleh Nurhadi. (2013) bahwa membaca sangat berpengaruh terhadap kemampuan matetematis sesorang, sangat sulit seseorang menyelesaikan persoalan matematis jika tidak paham apa yang menjadi masalah. Kemampuan membaca menjadi keharusan dalam menyelesaiakns esuau termasuk soal cerita amtematika.

Hasil penilaian ini, juga sesai dengan pandangan Wiryodijoyo, (2013) bahwa kemampuan membaca pemahaman merupakan bagian penting dari penyelesaian soal-soal matematika. Secara garis besar hubungan antara membaca dan menulis adalah sebagai berikut (1) Membaca (reseptif) dan menulis (produktif) (2) Menulis adalah kegiatan menyampaikan gagasan, pesan, informasi, sedangkan membaca adalah kegiatan memahami gagasan, perasaan, informasi dalam tulisan (3) Sebelum menyelesaiakn soal cerita matematika, seorang harus paham konsep yang akan dikerjakan dan menulis kembalii sebagai bagian dari implikasi pemahaman.

Hal ini juga menunjukkan bahwa seorang matematis yang baik harus juga seorang 
pembaca dan penulis yang baik. Berdasarkan hasil penelitian di atas, dapat dipahami bahwa dalam proses pembelajaran, siswa harus menyeimbangkan antara keterampilan berbahasa, terutama antara membaca dan menulis dan kemampuan matematis. Hal ini memang telah diamanatkan dalam kurikulum yang memperlihatkan keseimbangakn kompetensi adar yang akan dipelajari siswa. Demikian halnya pendekatan pembelajaran yang digunakan yaitu pendekatan komunikatif terpadu yang di dalamnya secara terpadu dilakukan peningkatan keterampilan secara seimbang.

Titis (2017) menegaskan bahwa siswa yang memiliki pemahaman yang baik terhadap bacaan, maka akan mudah dalam memahami masalah sehingga dapat menyelesaikan soal cerita dengan baik pula. Artinya jika siswa baik dalam membaca pemahaman, maka akan diikuti dengan kemampuan menyelesaikan soal cerita matematika yang baik pula. Begitu sebaliknya, apabila siswa memiliki kemampuan membaca pemahaman rendah, maka kemampuan menyelesaikan soal cerita matematika juga akan rendah.

\section{Kesimpulan dan Saran}

Unjuk menjawab pertanyaan penelitian diuraikan sebagai berikut: (1) Tingkat kemampuan membaca dan menyelesaikan soal cerita berada pada kategori sedang; (2) Terdapat pengaruh signifikan kemampuan membaca terhadap kemampuan menyelesaiakn soal cerita matematika; (3) Terdapat pengaruh signifikan kemampuan menulis terhadap kemampuan menyelesaikan soal cerita matematika; (4) Terdapat pengaruh signifikan secara bersama-sama kemampuan membaca dan menulis terhadap kemampuan menyelesaikan soal cerita. Berdasarkan kesimpulan maka dalam penulisan ini dikemukakan saran sebagai berikut: (1) Ada baiknya hasil penelitian ini dijadikan sebagai salah satu alternatif bagi guru dalam meningkatkan kemampuan mmembaca, menulis dan berhitung di sekolah dasar; (2) Ada baiknya hasil penelitian ini dijadikan sebagai penambah bahan kepustakaan yang berkaitan dengan hasil penelitian masalah keterampilan berbahasa dan hubungan keempatnya terutama membaca, menulis, dan berhitung; (3) Ada baiknya hasil penelitian ini dijadikan sebagai bahan penelitian lanjutan mengenai berbicara pada aspek bahasa Indoneisa lainny; dan (4) Ada baiknya hasil penelitian ini dijadikan dasar kebijakan pemerintah atau dinas pendidikan dalam kaitannya dengan membaca, menulis dan berhitung.

\section{DAFTAR PUSTAKA}

Abustam, M. Idrus. et al. 2006. Pedoman Praktis Penelitian dan Penulisan Karya Ilmiah. Makassar: Badan Penerbit UNM. 
Akhadiah, Sabarti. dkk. 1995. Pembinaan Kemampuan Menulis Bahasa Indonesia. Jakarta: Erlangga.

Alwi, Hasan, dkk. (ed). 2001. Kamus Besar Bahasa Indonesia Edisi III. Jakarta: Balai Pustaka.

Arikunto, Suharsimi. 1993. Dasar-dasar Evaluasi Pendidikan, Jakarta: Bina Aksara.

Darmadi, Kaswan. 1996. Meningkatkan Kemampuan Menulis. Yogyakarta: Andi Yogyakarta.

Dimiyati 2002. Keterampilan Berbahasa . Jakarta:Gema Media

Enre, Fachruddin Ambo. 1994. Dasar-Dasar Keterampilan Menulis. Ujung Pandang: Badan Penerbit IKIP Ujung Pandang.

Erik, Hendra Rudyanto. 2017 Pengaruh Kemampuan Membaca Pemahaman terhadap Prestasi Belajar Matematika Pada Pokok Bahasan Soal Cerita Kelas IV SD. Jurnal Kependidikan Dasar Islam Berbasis Sains Vol. 2 (2):175-182. December 2017.

Febriana Galih Mahardi. 2013. Pengaruh Keterampilan Membaca dan Minat Belajar Matematika terhadap Kemampuan Menyelesaikan Soal Cerita Matematika Siswa Kelas V SD. Jurnal Kalam Cendekia Kebumen. Vol.!. No.3

Ginting, Vera. 2005. Penguatan Membaca, Fasilitas Lingkungan Sekolah dan Perpustakaan. Jakarta: Gema InsanPress

Hadi, Sutrisno, 1987. Statistik jilid 2. Yogyakarta ;Fakultas Psikologi UGM Yogyakarta

Jailani. 1989. Pengaruh Kemampuan Membuat Modul Matematika Melakukan komputasi dan Tingkat Kelas Terhadap Kemampuan Menyelesaikan Soal Cerita Matematika pada Siswa SMP, Yogyakarta Skripsi Tidak di Terbitkan: IKIP Yogyakarta.

Lis Rukminisari, 2000, Kemampuan Menyelesaikan Soal Cerita Geometri Siswa Kelas V SD Negeri SE-Kelurahan Pleret Kabupaten Bantul Tahun Ajaran 1999/2000. Yogyakarta : JPMPA FKIP UST Yogyakarta.

Massofa, 2008. Pemerolehan Bahasa Pertama dan Kedua. (online) www. Massofa wordpress.com. diakses tanggal 01 Februari 2021

Mulyati,Yeti dkk., 2007 , Keterampilan Berbahasa Indonesia SD Modul, Jakarta: Universitas Terbuka

Mulyati. 2002. Keterampilan Menulis. Bandung: Remaja Rosdakarya

Nurgiyantoro, Burhan. 2001. Penilaian dalam Pengajaran Bahasa dan Sastra. Yogyakarta: BPFE.

Setiawan, Yasin.2009. Terobosan dalam Mengajar matematika. (online) (http:// www. Siatsof Network-Online.com.) diakses tanggal 01 Februari 2021

Sidjaja, Arman. 2005. Pembelajaran Keterampilan Berbahasa. Jakarta : Guna aksara. 
Sigit Widyanto 2017. Pengaruh Kemampuan Membaca Pemahaman terhadap Kemampuan Menyelesaikan Soal Cerita Matematika Siswa Kelas V SD. Jurnal Basic Education Vol. 6No. 3 Tahun 2017

Soedarso. 2001. Speed Reading: Sistem Membaca Cepat dan Efektif. Jakarta: Gramedia Pustaka Utama.

Sumiyatun, 1999. Hubungan Penguasaan Konsep dan Ketrampilan Hitung dengan Kemampuan menyelesaikan Soal Cerita Matematika Siswa Kelas I SLTP Negeri seKecamatan Wedi kabupaten Klaten Tahun Ajaran 1998/1999, Skripsi Tidak diterbitkan. Yogyakarta ; JPMIPA FKIP UST Yogyakarta.

Syafi'ie, Imam. 1994. Pengajaran Membaca Terpadu. Bahan Kursus Pendalaman Materi Guru Inti PKG Bahasa dan Sastra Indonesia. Malang: IKIP.

Tarigan, Henry Guntur. 1985. Membaca sebagai Suatu Keterampilan Berbahasa. Bandung: Angkasa.

Titis, Titis Harlin (2017) Hubungan antara Kemampuan Membaca Pemahaman dengan Kemampuan Menyelesaikan Soal Cerita Matematika Siswa Kelas IV SDN Se-Gugus 3 Imogiri Bantul Arum Jurnal Universitas PGRI Yogyakarta. Voll November 2017.

Tria, Rosselina Andanik 2014. Pengaruh Keterampilan Membaca Pemahaman terhadap Kemampuan Pemecahan Soal Cerita Matematika Siswa Kelas V Sekolah Dasar. Jurnal Fundadikdas

ISSN: 2614-1620. 2014

Zuchdi, Darmiyati. 2007. Strategi Meningkatkan Kemampuan Membaca: Peningkatan Komprehensi. Yogyakarta: UNY Press. 